\title{
Agricultural employers' representation and rationalisation of their work offer
}

The 'benevolent moderator'

Johan Fredrik Rye and Sam Scott

\section{Farmers and precarious work: perpetrators or victims?}

An abundant literature has detailed the precarious work and everyday living conditions experienced by migrant farm workers in the horticultural industries in Europe (Gertel and Sippel, eds. 2014, Corrado et al. 2016, Rye and Scott 2018) and the US (Wells 1996, Holmes 2013) and Canada (Bélanger and Candiz 2015). Extreme yet not exceptional cases include 'quasi slavery relations' (Bock et al. 2016), housing in 'ghettos' and slums (Perrotta 2017, 2015), exposure for sexual abuse (Andreu and Jiminez 2010, quoted in Lindner and Kathman 2014), racist treatment, discrimination (Papadopoulous and Fratsea 2017, Hellio 2017, McAreavey 2012), and other examples of de-humanising practices. Holmes (2007, 50-51) describes a 'hierarchy of suffering' in which different migrant groups are pitched against each other:

The further down the ladder one is positioned, the more degrading the treatment by supervisors, the more physically taxing the work, the more exposure to weather and pesticides, the stronger the fear of the government, and the less control one has over one's own time.

In the literature, the prevalence of 'gruelling' working conditions (Guthman 2017a, 2014) is usually framed with reference to the structural drivers of the contemporary capitalist food production system (Farinella and Nori, Chapter 5). The global agri-business value chain - made up of producers, processors, distributers, marketers, financial institutions, retailers, and others - is driven by the dynamics of capitalism. Most obviously, productivity and efficiency are positioned as key to profitability and through this capitalist logic the (migrant) manual farm worker becomes more 'structurally vulnerable' (Quesada et al. 2011) than any other actors.

In this chapter, we explore this landscape from the intermediate level in the food value chain by examining the perspective of the employer/farmer. At the intersection between the interests of labour and capital, farm employers have first-hand knowledge of the everyday plight of the (migrant) workers 
they employ but are also aware of the larger demands of the food industry. In short, they are mediators and moderators, often in the apparently impossible position of acting ethically in relation to their employees, making a good living for themselves and their families, while responding to the demands of the market. Holmes $(2013,2007,54)$, in his widely acknowledged work on the suffering of US migrant farm workers, therefore argues that we should conceptualise farmers '.. as human beings trying to lead ethical, comfortable lives, committed to the family farm in the midst of an unequal, harsh system,' if we want to better understand their social practices as employers, even when these imply exploitative working arrangements.

It is outside the reach of the current research to evaluate farmers' 'objective' conditions or to discuss their social responsibilities for migrant farm workers' conditions, or capacities to alter these, which are all relevant research topics. This chapter rather examines the farmers' contradictory position between the interests of labour and capital by exploring how they develop discursive strategies to makes sense of their everyday practices as employers. We ask, specifically: How do low-wage employers rationalise the pay and conditions they offer their (migrant) workers? In posing this question the chapter responds to Holmes' (2013) and other (see Scott 2013a) calls for research to better conceptualise the perspectives of the employer.

\section{Strawberries in the US, the UK, and Norway}

To examine similarities and differences in the ways employers 'talk about' lowwage migrant labour, we conducted qualitative interviews with strawberry farmers in three locations: the US (California), the UK, and Norway. The strawberry industry offers an instructive case-study for international research and has many similar features irrespective of location. Most important are the biological properties of the berry (lat.: Fragaria). Strawberry production has a shorter time horizon than many agricultural products and investments can pay off over the course of a few years. Thus, even though profits can be volatile with weather, plant disease, and rapid changes in market demand playing a part, the strawberry has been called the 'red gold' of agriculture (Hellio 2008, i).

Over recent years, biological innovations (e.g. breeding programmes, genetics, pesticides), changes in production (e.g. variants of polytunnels/ greenhouses), and organisational shifts (e.g. value chain integration, including on a global scale) have transformed the strawberry industry in many countries. At one extreme are the global corporations with involvements at all stages of the value chain, often backed by non-agricultural finance. At the other extreme is the family farmer cultivating a few hectares of berries and often relying on direct sales to the consumer. Calleja et al. (2012), studying the historical development of UK strawberry industry between 1920 and 2009, identifies the recent polarisation of the industry into two business models. 
The first is 'productivism,' characterised by intensification, concentration, and specialisation. The second is 'post-productivism' which in essence refers to the remnants of a more traditional mixed-farming system, now threatened by competition from the 'super-productivist' farms specialising only in strawberries and making much larger investments in technology and innovation. The introduction of polytunnels, for instance, drastically extended the production season and quality of berries (Evans 2013) and favoured productivist and super-productivist growers in the early stages. In addition, there are often geographical clusters of these type of growers: Spain's 'sea of plastic' in the Huelva region and Greece's rural Manolada district (where about 20 farmers employ some 3,500 workers and produce 90 per cent of the country's strawberries) spring to mind (Gialis and Herod 2014).

Consistent across time and space is the labour-intensive character of strawberry production, although efficiency has increased over recent years particularly with the introduction of table-top growing. Wage costs account for about 50 per cent of total production expenses and constitute the key variable for the strawberry farm's profitability. Picking demands not only a high level of labour but also 'good' labour. The sensitive berry demands careful, considerate, and dedicated workers and what farmers call 'delicate hands' (Hellio 2008, vi). Also important is workers' ability and willingness to endure the work in the strawberry fields, which by nature is physically demanding, monotonous, and has little to offer in terms of personal fulfilment. While practical skills are required, the harvesters need no formal education, and the picking process is possible to acquire in the matter of days (though it can take much longer to get up to the top picking speeds). As in other agricultural production:

The most important reason for hiring migrants - instead of locallnative workers - is their readiness to accept jobs for which vacancies have been difficult to fill; often this means jobs that are physically demanding, with unpredictable working schedules, long hours of work, offering poor pay and low social status.

(Bock et al. 2016, 76)

The strawberry industry - from the industrial, global agri-business to the small-scale family farmer - has come to rely on low-paid migrant farm labour. However, more than simply being low paid, the strawberry industry has been accused of being highly exploitative. According to Ivancheva (2007, 116), no other horticulture product line has been as frequently witness to sub-standard working conditions as the strawberry industry. Numerous other papers have been published detailing the exploitative labour conditions in the industry in Europe (e.g. Mannon et al. 2012, Hellio 2008, 2017) and particularly in the US (for instance, Schlosser 1995, Wells 1996, Sanchez 2013, Guthman 2017a, 2017b). Thus, while food production, more generally, has been associated 
with intensification and exploitation (Rogaly 2008, Scott 2017), it is a problem that appears particularly pronounced within the strawberry sector.

In this chapter, we draw on materials from a comparative study of the strawberry industries in three localities in the western world: The Watsonwille/ Salinas district in California, US; west and southwest England in the UK; and Trøndelag in Norway. These are identified as interesting 'contrasting' cases (Yin 2009) as they represent three different societal contexts as well as agricultural systems.

California hosts one of the world's most industrialised agricultural production systems. Its strawberry industry accounts for 88 per cent of the total US production and 20 per cent of world production (Guthman 2017a). The production is centralised to a few locations along the Californian central coast with particularly good soils and superb climatic conditions. The population of farmers and their organisational structure are heterogeneous. Manual labour at the farms is exclusively provided by migrants originating in Mexico or other Latin-American countries. Some are recent arrivals in the US and had planned to return, in theory constituting circular migrants. However, recent changes to US immigration policy and implementation has made it more difficult to cross the US-Mexico border. In effect, many of today's workers are now long-term residents in the US, roughly split into two equalsized groups of those with and those without legal papers (Martin 2019). The US labour market is less regulated than the UK and Norwegian labour markets, reflecting general differences in societal models. However, California has more progressive labour regulations than most other US states and, importantly, these also apply to the agricultural sector. Despite an interesting history of trade unionism (Mireles 2013), today there are no organised labour movements within the strawberry industry.

Norway's strawberry industry - relative to the Californian case - has a small-scale and highly seasonal character. Farms are few, small, and dispersed around the country; most are the only ones growing strawberries for miles around. Most are owned and operated by family farmers, exclusively of Norwegian ethnic origin, who also live on the farm and participate in daily operations. If California represents the 'super-productivist' business model (Calleja et al. 2012), Norway is the 'post-productivist' model, exclusively serving the domestic market. The Norwegian strawberry industry is, as the agricultural industry at large, strongly regulated by the state - however in an intimate interaction with industrial representatives, both from farmer associations and agri-business agents (Rye 2017). From this chapter's perspective, the (relatively) extensive and worker-friendly labour market regulations are of particular importance. After trends towards 'informalisation' of the farm migrant labour market around 2000, later years have been characterised by a process of 're-formalisation' of labour relations, with improving wages and working conditions (Rye 2017). While not present at the farm level, trade unions have a strong voice in labour market regulation and rights to bargain 
on behalf of workers, including non-union members. Starting in the 1990s, Norwegian strawberry farmers have increasingly come to rely on migrant labour from eastern, central, and southern Europe. Work is predominantly circular and seasonal.

The UK strawberry industry represents an interesting middle point between the US extreme of super-productivist and Norwegian post-productivist horticulture production, both in terms of production structure, technologies, and harvests. Almost all of the UK crop is for home consumption with very little export production (Defra 2018). There is some but limited geographical clustering of the industry. Since early 2000s, there has been a heavy dependency on Polish labour for strawberry harvesting but now it is largely Bulgarian and Romanian workers employed in seasonal roles. As in Norway, labour is often circular in nature (though the UK growing season is longer) and labour generally lives on-site rather than in the local community (as occurs in the US). In terms of labour market regulation, the UK represents a middle ground between the US and Norwegian models.

\section{Researching employers' talk - materials and methods}

The core research question for our study presented in this chapter was: how do low-wage employers rationalise the pay and conditions they offer their (migrant) workers? The material to inform our answer to this question comes from 15 in-depth interviews with strawberry producers in the three study localities: Watsonville in California, US; the west and southwest of England, UK; and Trøndelag, Norway. Given the nature of the research topic (farmers' talk around low-wage and seasonal labour), we sought to capture the dominant discourses that are constructed and reproduced, and we work to provide collective accounts of social practices, both descriptively and normatively. To this end, informants were approached as representatives of their social category ('strawberry farmers') and we were less interested in their unique personal histories. The enduring impression from the interview encounters was that informants willingly, and with confidence, took on the role as industry 'spokespersons.'

The sampling process sought to cover a variety of informants in terms of characteristics of farmer (age, gender, farming history) and farm (size, production technologies, conventional/ organic, value chain integration). The heterogeneity varied between study localities; higher in California, lowest in Norway. The objective was to include voices from different positions in the social landscape of strawberry farming in each of the localities, both to add nuance and to identify potential contrasting and/or contesting discourse. While further materials possibly would fortify the analysis, five interviews in each locality appeared enough to reach a 'saturation point' (Bloor and Wood 2006).

The interviews were semi-structured and covered topics of relevance to the farmers' labour recruitment and employment strategies past, present, and 
future. The interviews were flexible and allowed the informants to bring up topics they found relevant, and for the interviewer to follow up on these. Thus, the structure of interviews differed between individuals (e.g. due to personal experiences) and between localities (e.g. in Watsonville questions on immigration policy were salient, in west and southwest England questions on Brexit were salient, and in Norway experiences with trade unions were relevant). The farmers were not explicitly confronted with the academic literature's documentation of precarious living and working conditions for migrants on farms in advanced economies; however most did, through their own initiative, provide thoughts on the welfare and quality of work and life for migrants in the strawberry industry.

The data gathered through low-wage employer interviews is evidently one viewpoint on to the labour process. This partial approach was purposeful: we wanted to examine the presence of hegemonic low-wage employer discourses in the strawberry industry across different country contexts. In other words, we were interested in the stories that employers tell about the labour that they employ and how they rationalise the low-wage and seasonal opportunities they provide.

Interviews were conducted by the authors in the farmers' native language. Conversations lasted for about 60-80 minutes and were recorded. Interviews were transcribed by professional transcribers, and published testimony has been anonymised to protect interviewees' identities. Translations of the Norwegian quotes are by the authors. Further detail on the materials is provided in Scott and Rye (forthcoming). All interviewee names have been changed to pseudonyms.

Importantly, the chosen research strategy cannot capture the 'objective' realities of (migrant) farm work, which was never the intention. Tapping into employers' talk and rationalisations of their practices provides information about exactly that: their discursive representations. Other methodologies, preferably involving a mixed methods approach, are required to gain complementary accounts of employment relations and practices, as we have done in other papers (see for instance, Rye and Andrzejewska 2010).

\section{Picking strawberries as 'tough but rewarding work'}

Despite the numerous academic accounts of low wage and seasonal horticultural work being extremely tough, and by some accounts increasingly exploitative (Rye and Scott 2018, Scott 2017, Bock et al. 2016, Holmes 2013, Rogaly 2008), the employers we interviewed were universally prone to rationalise the pay, work, and living conditions they provided in a very positive manner. Migrants may constitute the archetypal 'good worker' (Baxter-Reid 2016, MacKenzie and Forde 2009, Tannock 2015) and this was also the case for the informants (Scott and Rye, forthcoming) but in our research we also uncovered a strong and consistent 'good farmer' discourse across the study 
localities. Specifically, while low-wage seasonal picking work is unquestionably tough and demanding, employers first and foremost positioned it as economically rewarding and, furthermore, also positioned themselves as socially responsible employers.

This positive rationalisation, which emerges despite the fact that employers occupy a constrained, and somewhat impossible, position between the demands of capital and labour, will now be examined in detail. We demonstrate how the farmers construct themselves as 'benevolent moderators,' despite a highly constrained structural context, and the presence of relatively harsh wage and working conditions. Moreover, this narrative appears consistent as the dominant story employers tell across diverse study locations and across farm types.

\section{The good work narrative}

Farmers' presentation of their work offer was underpinned by an apparently solid conviction that strawberry work is 'good work.' By offering employment largely to migrants from less affluent societies, farmers claimed to provide them with a much-needed source of income and allow them to improve their living conditions and quality of life in both the home and host countries. The income from farm work was argued to be good both in an absolute and relative sense. Farmers contended that strawberry picking paid well in comparison to other (farm) jobs available in the study locations (piece-rate bonuses - where workers are paid according to output - were often mentioned as a major advantage to the migrant workers employed). Moreover, they also argued that hard-working migrants could earn wages that were excellent when compared with wages in the migrants' home countries, i.e. when considered within a 'dual frame of reference' (Suárez-Orozco and Suárez-Orozco 1995, Waldinger and Lichter 2003). Californian informant Cole found the workers' affluence apparent to all, as evidenced by their cars: 'Go look at what my employees drive. They drive BMWs. They drive newer cars. Newer than mine.' Other informants would provide similar examples to demonstrate the good, or at least reasonable, material living standards of their workers.

None of the informants did at any time provide examples to the contrary; of migrant workers' poverty or failure to succeed. Insofar as stories of exploitation emerged in the interviews, they were explained by the exceptional 'bad egg' employer or intermediary and/or with reference to erroneous accounts constructed by (biased) urban media outlets. Certainly, the voluminous literature on workplace exploitation and job intensification in food production (for instance, Scott 2017, Rogaly 2008) has never found a receptive readership among agricultural employers.

Furthermore, in Norway and (at the time of interviews) pre-Brexit England, circular seasonal migration is legally and practically quite feasible for eastern and central European migrants. Particularly in the Norwegian case, workers 
would move back and forth and spend the larger part of the year 'at home.' In the UK, where the growing season is longer, time spent back home was more limited but still significant. Against this circulatory context, farmers emphasised how their migrant workers would make their earnings pay on a transnational level. For instance, Norwegian farmer Eirik detailed how the younger migrants used the money earned to both boost their current living conditions and to invest in educational careers in their homelands.

The students, obviously, are here to finance their studies, some of those with good jobs... they spend what they make here on luxurious goods. To be straight. The money goes to luxury, to live some kind of luxurious life.

The farmers emphasise the migrants' 'dual frame of reference' to underline that wages for them are even better within a transnational context. Interviewees would often provide specific comparisons between wage levels 'here' (host country) and 'there' (home country), and argue that middle-class migrants accept what might appear to domestic workers as low wages because of these different reference points. This is what Nieswand (2014) refers to as the 'status paradox of migration': poor pay abroad is still good at home. Thus, Anders (Norway) explained his workers' preference for piece rates often introduced by farmers to intensify the work process (Rogaly 2008) - by the opportunity they provide relative to what is on offer back home:

Cause they see the potential, right? 'Wow - I may pick two boxes per hour, three boxes! I have those making 2,500-2,600 [about £235] a day. And that is more than a months' wage in Lithuania, on the minimum wage in Lithuania.

Similarly, Trevor (UK) told how his workers ' ...can come, earn 11,000 GBP as quick as you can and then go and build your house for six months, that's quite a nice, quite a nice way of doing it, isn't it?' Such 'delayed gratification' (Scott 2013b) not only motivates migrants to endure the hardships of work, but also allows their employers to judge wages on standards other than those of the domestic economy.

In California, due to the recent tightening of border controls, workers are now less circular in their migration patterns. They also tend to live off-farm in the local communities (unlike in the UK and Norway). Their US wages are therefore spent largely in the US, and thus the 'dual frame of reference' and principle of 'delayed gratification' are of lesser relevance. However, strawberry picking may, according to employers, still function as a springboard for social mobility. Second generation strawberry farmer Eva (California), for example, detailed how laborious work may provide future prosperity, not just for the worker but also for his/her offspring: 
My father started the farm in 1978 (...) He was still working for another employer at that time (...) and he started there with the mentality that 'one day I can do this myself and I'm gonna have my own farm.' He started there.

In this way the employment of one migrant worker is, according to farmers, good for the many. Incomes from hard farm work provide opportunity for the larger migrant community. UK farmer Paul, in the context of a recent media scandal involving the food industry and migrant workers, criticised the media coverage for its one-sided perspective, ignoring the larger societal benefits of the industry's employment of migrants:

And we are employing people, these people are going back home, building houses and feeding families, yeah. You know, for everyone person we employ that's 10 people that we are actually feeding in one way or another. Why not look at that as positive?

The informants also underlined that strawberry picking provided benefits other than remuneration. Many emphasised how many migrants used strawberry work for travelling and adventure, exploring the world, even as a 'holiday.' Again, this motive was more prominent in the UK and Norway. Norwegian farmer Eirik, for instance, talked about his female workers:

Well, for some of them, it is kind of a holiday. Particularly those mothers with smaller kids at home, almost... I did get it but more recently I have come to understand, that, they are friends [knowing each other since childhood] coming here, kind of housewife's holiday. Getting away from their husbands or kids for a period, and that is good.

The farmers are able to corroborate their overwhelmingly positive account of strawberry picking via a number of discursive strategies. Most important is the 'workers voting by their feet' argument: the rewards of strawberry picking are evidenced by high number of returning workers, year after year. Eirik (Norway) described his female workers' obvious like of the work:

Most of them come back, and if they do not, they often send their mother, the sister, or a friend. And that would not be if they not were [satisfied]. (...) Some families have been her for three generations, and some have worked for 10-15 years.

In other regards the workers appear satisfied. Most notably, farmers emphasised that they rarely received any complaints from the migrants they employed. However, many also admitted that if they were not happy with a migrant's work rate (which is constantly monitored) they would either be 
warned then eventually dismissed, or simply not invited back the following season.

In Norway and the UK (though not in the US), farmers emphasised how many of their workers held or hold good job positions back home; for instance as managers, teachers, and other professional occupations. For the farmer this works to confirm that the migrants they employ do not represent precarious workers. Victor (UK), for example, talked about the origins of his eastern European workforce:

You know, I've had doctors, university faculty lecturers, you know, vets, all sorts of people work for me in, in the course of time. (...) I had - one guy was a university faculty lecturer and he had 12 lecturers under him and he could earn more money picking strawberries for six months in the UK, than he could in a year being, being a top lecturer, you know.

From the perspective of the farmers, the legal and ethical soundness of the labour arrangements they preside over are confirmed via the actions of external authorities. Wage levels are set by legislative bodies in all three localities. These are strictly observed, according to informants, both by themselves and the industry at large. If anything, employers argued that they exceeded the baseline regulations because of the opportunities provided to workers, for example through the piece-rate system and other bonus mechanisms (though see Rogaly 2008). Daniel emphasised that he paid out annual bonuses to his workers, and other informants similarly told about how they rewarded their better pickers more than was required by law.

In the opinion of the informants, wages and working conditions have improved over the years. UK farmer Rosalyn implicitly acknowledged the harsh work conditions of the past, but stated that farmers now have no choice but to follow rules and regulations: 'Gone are the days you can treat them like a slave (...). I have to be legal, I have to have health and safety, got to comply.'

In conclusion, the farmers emphasise their role as providers of 'good work,' which to them is an integral aspect of being a farmer; they do not only produce food but also provide careers and opportunities for the migrants they employ. Once again, we emphasise that these are discursive accounts presenting the employer perspective and not 'objective' descriptions of the realities of work. Nevertheless, these accounts provide insights into the ways that employers rationalise their position between capital and labour, and make sense of the low-wage migrant employment practices that they are engaged in.

\section{The socially responsible employer}

The employers we interviewed further expressed their benevolence by emphasising how their responsibilities towards the migrant workers extended beyond a pure economic and contractual relationship. Their workers were not 
just workers but part of a team and a family, with attendant social obligations and caring duties attached. For Californian small-scale strawberry farmer Eva, the workers were 'family':

With us, we treat them like family. Once a week, I will treat my employees. I will take them lunch, I will take them breakfast, coffee in the morning (...) ...usually for Christmas, my mother will make dinner, family will get together and they'll come. All of our employees know all my brothers, all my family, my aunts, my uncles, they've all worked with us. Yeah, it's like a big party. (...). Actually, some of the employees have married my cousins.

Most strawberry farms employ large numbers of migrant workers in the high season and so the farmer cannot nurture intimate social relationships with all employees, especially as many are temporary. Nonetheless, the narrative of the socially responsible farmer appeared strong across study locations. For instance, Cole, a US farmer with a larger workforce, described how his whole family were involved with the care for their workers. His dad:

... tries to, whenever he can, take a group of employees, as soon as he can, take them to Vegas or Reno to show them the different places, not just work. On their own, they won't go. Very few of them will go. If they do go out, they go to places that they know it's people like them around there.

Similarly, Norwegian Daniel, recalled how they '... have a party every year, to mark the end of the strawberry season. And every year we do a hike in the mountains, for a weekend or so.' Other employers shared similar stories of facilitating social life on the farm.

Furthermore, the informants recalled how they regularly assisted workers in their often troublesome interactions with local bureaucracies. Rather than employers exploiting their workers, the informants placed themselves as allies of their workers in their encounters with officialdom.

In the US case, the US-Mexico border was a recurring theme. While the US farming community generally leans towards the Republican party, our informants - in line with other agricultural employers - were concerned about the current (Trump) administration's tightening of the border. They argued the policy reduces the availability of migrant workers and places many already in the US in a more vulnerable position. Adam (US) explained:

There came a point where it became increasingly difficult to pass through the border to get down to Mexico, and people stopped taking those breaks over winter. They essentially chose to stay here year round, so we felt somewhat obligated to provide more employment over winter, and we decided to do an, every other week, delivery on our produce boxes through the winter months, from November until March, and that's worked out well. It's provided more 
work for the crew during the wet, rainy months, and that was partially a concession to provide more hours for the people that were working for us.

This emphasis on care and support for migrant workers was commonplace across study locations. Spencer (UK), for instance, emphasised how:

We try and care for them (...) they all know me and my main supervisor is very caring because I explained to him that they are the most important part of the farm and without them we'd give up. So, they need caring for and time spent caring for them.

The informants present themselves as socially responsible and they see their role as good employers extending well beyond the narrow economics of the contractual wage relationship. They see themselves as decent people, following the adage: 'You know, I treat people as I would expect to be treated myself' (Trevor, UK).

Irrespective of the 'objective' reality of low-wage agricultural work, the informants appeared genuine as to their intentions of treating workers respectfully. They emphasised, for instance, how their consideration for workers' welfare can impact upon the very operation of the farm, and even incur economic costs. US informant Dennis stressed how he would never risk the health of his workers: 'We value a person's life over an hour of work.' To illustrate this, he told of a particularly hot day the year before, where temperatures reached 95 degrees Fahrenheit (35 degrees Celsius). Workers wanted to keep picking regardless but, in the end, Dennis had to force workers to leave the field:

I'd rather pay you an hour out of my pocket, you guys go home. It's just too hot. We're not gonna put somebody's life in danger because we want to produce an hour worth of labour.

Anders, referring to a discussion with a representative of the shipping company, underscores that the welfare of workers is more important than profits. He adamantly stated that he would never consider lowering wages in order to enhance profits.

I told him, if that what it takes to make a surplus - reducing the wages of workers, or even go down below the legal minimum wage... If that what it takes to stop worrying for the farm, not sleeping at nights... Then I quit farming. End of story.

None of the informants provided examples to the contrary, and appeared unaware of the extensive literature detailing work-based harm related to the hardships of manual farm work, such as strawberry picking (Holmes 2013, Scott 2017). 
The informants in all three localities identified a relationship between the good treatment of workers and a productive and happy workforce. Employment intermediaries/agencies, for instance, were avoided by many because of the potential for exploitation. Trevor (UK) explained:

So we have our own recruitment team, which I'm responsible, so-and that's not, that's not really done for cost, it's more done for ethical reasons. There is, there is perhaps a, a better, a slightly better cost side of it, but it's more we've got the control.

More broadly, many talked about the importance of recruitment and retention in a tight labour market, and how this translated into excellent living and working conditions. UK farmer Patrick explained:

To retain the people, as well, you know, they've left their families behind and they've come here. So, we try to offer them a home environment here so they can enjoy their life as well. Not just working so the leisure time - they can do many things because the campsite is really nice, they have a football ground there, a pool table is there just to make their life easier and more enjoyable.

According to Trevor (UK) good-quality living and working conditions had become 'pretty industry standard' now. Particularly where labour shortage appears more prevalent in employers' discourses (in the US given Trump's border restrictions and in the UK given Brexit) the need to provide attractive work was seen as imperative. Rosalyn (UK), quoted above on the industry no longer treating workers as 'slaves,' openly stated that they had no other choice: they needed to compete for workers now and it was the worker who could decide where to pick, and the farmers were at their mercy.

The informants sought to establish a narrative of equality, where farmers and migrants - employers and employees - shared the same interest. Hard work and a good harvest are viewed as to the mutual benefit of both parties; they depend on each other to make the strawberry fields a source of shared profit. In this storyline, the undoubted hardship of migrant manual work in the fields is rendered invisible. More than anything, strawberry picking is presented as good work for good workers, provided by socially responsible and benevolent employers.

\section{Integrating interests of labour and capital}

Drawing on the strawberry industry in the US, Norway, and UK, this chapter set out to examine how low-wage agricultural employers rationalise the pay and conditions they offer their (largely migrant) workforce. Despite numerous accounts emphasising the exploitative nature of the strawberry industry, and indeed horticulture more generally (Rye and Scott 2018, Scott 
2017, Bock et al. 2016, Holmes 2013, Rogaly 2008), the stories employers told us emphasised positive moral and ethical dimensions to migrant employment in labour markets that often appear harsh and unyielding to the outsider. As a consequence, one is presented with a 'good farmer' discourse that draws on the transnational frame of migrant employment (Suarez-Orozco and Suarez-Orozco 1995, Scott 2013b, Waldinger and Licther 2003) and also on the importance of the socially responsible employer. Resonant with Weber's ideal types of human action (1968 [1921]), low-wage employers claim to operate according to the logics of both economically rooted means-ends rationality and a value-oriented rationality. They act as homo economicus and homo socius, and seek to demonstrate how these rationalities are complementary rather than contradictory. In this respect, and given low-wage employers' location between capital and labour, one can conclude that farmers see themselves as 'benevolent moderators' who successfully manage to combine the economic necessities of the strawberry industry, providing 'good workers' with 'good jobs,' and doing so in socially responsible and ethically sound ways.

What is missing from farmers' rationalisation of their work offer is the critique of the structural context within which they are embedded and through which they must operate. The farmers do not openly question the 'natural' order of the contemporary world but accept it as given both in terms of their position in the food value chain and in terms of their migrant workers' position relative to the rest of society. The stories they tell contain an element of 'misrecognition' by taking reality for granted (Bourdieu 1990), or at best a public 'silence' with respect to the possibility for alternatives both for themselves and their workers. They are then, to an extent at least, captives of dominant discourses (Foucault 1972): whether through misrecognition or a more conscious and considered silence. This may not be purely incidental or contrary to their interests; the silence possibly works to bolster their relative privileged status vis-à-vis their workers, or at least uphold the status quo.

Another omission from the 'good work' discourse, and this relates to the structural silence noted above, is any real acknowledgement that the temporary, seasonal, and low-wage work offer is exploitative. The strawberry picker generates surplus value but is largely disenfranchised from this. There is a paradox, then, whereby employer exploitation and employer benevolence appear to be co-located at the bottom of the labour market across developed world horticulture. This is entirely feasible; most obviously employers (like most people) are prone to present their actions in a positive light. More than this, however, one gets the sense that the economic arguments (that work pays for migrants) and moral arguments (that employers are socially responsible) that farmers made were genuine rationalisations rather than cover stories. In short, farmers - in their own accounts - find themselves in a conflicted position between capital and labour and felt they did the best they could in the face of the competing pressures. 
Overall, the chapter has emphasised striking similarities in strawberry farmers' representation and rationalisation of migrant workers' (relatively low) wages and (relatively tough) working conditions. The informants' accounts are largely uniform in their structure, both within and across study locations, and appears to reflect a dominant 'good work' discourse and the associated role of farmers as 'benevolent moderators' between capital and labour. Nevertheless, the materials do suggest some geographical nuances in farmers' representation and rationalisation. For instance, as briefly noted above, the US context of immigration policy reform, the UK context of Brexit, and the Norwegian trade union context are all noteworthy. In terms of future research, it would be interesting to explore these nuances in more detail. In addition, alternative methodologies could be used to challenge or corroborate the stories employers tell. For instance, the global leader of the strawberry industry, Driscoll's, details on its webpages how it retains a thriving workforce in phrases echoing the informants in this chapter: 'Treating the workforce with dignity isn't just the right thing to do, it's crucial to the future of our business' (Driscoll's 2020). Moving beyond the employer, it would also be interesting to examine workers' responses to the employer discourse identified. One could also examine whether the employer representations and rationalisations profiled above are reflected in other low-wage sectors of the economy (such as care work, cleaning, hospitality, food processing) or are farmers unique in their 'benevolent moderator' role?

\section{Acknowledgements}

The chapter is result of the 2017-2022 Global Labour in Rural Societies research project financed by the Norwegian Research Council (grant no. 261854/F10). The authors wish to thank the external reviewers for their comments on the manuscript. Funding from the Norwegian University of Science and Technology has made possible open access publishing of the chapter.

\section{References}

Baxter-Reid, H. 2016. 'Buying into the "Good Worker" Rhetoric or Being as Good as They Need To Be? The Effort Bargaining Process of New Migrant Workers.' Human Resource Management Journal 26: 337-350.

Bélanger, D. and G. Candiz. 2015. 'Fraises douces amères: territoire et précarité chez les travailleurs agricoles migrants de la région de Québec.' Cahiers de géographie $d u$ Québec 59(166): 7-28.

Bloor, M. and F. Wood. 2006. 'Theoretical Saturation.' In Keywords in Qualitative Methods, edited by M. Bloor and F. Woods, 156-166. London: Sage.

Bock, B., G. Osti and F. Ventura. 2016. 'Rural Migration and New Patterns of Exclusion and Integration in Europe.' In The Routledge International Handbook of Rural Studies, edited by M. Shucksmith and D. Brown, 71-84. New York: Routledge: 71-84. 
Bourdieu, P. 1990. In Other Words. Essays Towards a Reflexive Sociology. Cambridge: Polity Press.

Calleja, E.J., B. Ilbery and P.R. Mills. 2012. 'Agricultural Change and the Rise of the British Strawberry Industry, 1920-2009.' Journal of Rural Studies 28(4): 603-611.

Corrado, A., C. de Castro and D. Perrotta, eds. 2016. Migration and Agriculture Mobility and Change in the Mediterranean Area. London: Routledge.

Defra (Department of Environment, Food and Rural Affairs. 2018.) 'Horticultural Statistics.' Accessed 5 May 2019. www.gov.uk/government/statistics/latesthorticulture-statistics.

Driscoll's. 2020. 'Thriving Workforce.' Online information brochure. Accessed 29 March 2020. www.driscolls.com/ about/thriving-workforce.

Evans, N. 2013. 'Strawberry Fields Forever? Conflict over Neo-productivist Spanish Polytunnel Technology in British Agriculture.' Land Use Policy 35: 61-72.

Foucault, M. 1972. The Archaeology of Knowledge and the Discourse on Language. New York: Phanteon Books.

Gertel, J. and S.R. Sippel, eds. 2014. Seasonal Workers in Mediterranean Agriculture. Abingdon: Routledge.

Gialis, S. and A. Herold. 2014. 'Of Steel and Strawberries: Greek Workers' Struggle Against Informal and Flexible Working Arrangements During the Crisis.' Geoforum 57: $138-149$.

Guthman, J. 2014. Agrarian Dreams: The Paradox of Organic Farming in California. Oakland: California: University of California Press.

Guthman, J. 2017a. 'Paradoxes of the Border: Labour Shortages and Farmworker Minor Agency in Reworking California's Strawberry Fields.' Economic Geography 93(1): $24-43$.

Guthman, J. 2017b. 'Life Itself Under Contract: Rent-seeking and Biopolitical Devolution Through Partnerships in California's Strawberry Industry.' Journal of Peasant Studies 44(1): 100-117.

Hellio, E. 2008. 'Importer des femmes pour exporter des fraises (Huelva).' Etudes rurales $182,185-200$.

Hellio, E. 2017. "'They Know That You'll Leave, Like a Dog Moving onto the Next Bin". Undocumented Male and Seasonal Contracted Female Workers in the Agricultural Labour market of Huelva, Spain.' In Migration and Agriculture. Mobility and Change in the Mediterranean Area, edited by A. Corrado, C. de Castro and D. Perrotta, 198-216. London: 6.

Holmes, S.M. 2007. " "Oaxacans Like to Work Bent Over”: The Naturalization of Social Suffering Among Berry Farm Worker.' International Migration 45(3): 39-68.

Holmes, S.M. 2013. Fresh Fruit, Broken Bodies: Migrant Farmworkers in the United States, Berkeley: University of California Press.

Ivancheva, M. 2007. 'Strawberry Fields Forever? Bulgarian and Romanian Student Workers in the UK.' Journal of Global and Historical Anthropology 49: 110-117.

Lindner, K. and T. Kathmann. 2014. 'Mobility Partnershops and Circular Migration.' In Seasonal Workers in Mediterranean Agriculture. The Social Costs of Eating Fresh, edited by J. Gertel and S.R. Sippel, 121-129. London: Routledge.

MacKenzie, R. and Forde, C. (2009). 'The Rhetoric of the "Good Worker" versus the Realities of Employers' Use and the Experiences of Migrant Workers.' Work, Employment and Society 23: 142-159. 
Mannon, S.E., P. Petrzelka, C.M. Glass and C. Radel. 2012. 'Keeping Them in Their Place: Migrant Women Workers in Spain's Strawberry Industry.' International Journal of the Sociology of Agriculture and Food 19: 83-110.

Martin, P. 2019. 'Trump, Migration, and Agriculture.' Crossing Borders 9: 9-27.

McAreavey, R. 2012. 'Resistance or Resilience? Tracking the Pathway of Recent Arrivals to a "New” Rural Destination.' Sociologia Ruralis 52(4): 488-507.

Mireles, G.F. 2013. Continuing La Causa. Organizing Labor in California's Strawberry Fields. Boulder, Colorado: FirstForumPress.

Nieswand, B. 2014. 'The Burgers' Paradox: Migration and the Transnationalization of Social Inequality in Southern Ghana.' Ethnography 15(4): 403-425.

Papadopoulos, A.G. and L-M. Fratsea. 2017. 'Migrant Labour and Intensive Agricultural Production in Greece. The Case of the Manolada Strawberry Industry.' In Migration and Agriculture. Mobility and Change in the Mediterranean Area, edited by A. Corrado, C. de Castro and D. Perotta, 128-144. London: Routledge.

Perrotta, D. 2015. 'Agricultural Day Laborers in Southern Italy: Forms of Mobility and Resistance.' South Atlantic Quarterly 114(1): 195-203.

Perrotta, D. 2017. 'Processing Tomatoes in the Era of the Retailing Revolution. Mechanization and Migrant Labour in Northern and Southern Italy.' In Migration and Agriculture. Mobility and Change in the Mediterranean Area, edited by A. Corrado, C. de Castro and D. Perrotta, 58-75. Abingdon: Routledge.

Quesada, J., L.K. Hart and P. Burgeoise. 2011. 'Structural Vulnerability and Health: Latino Migrant Laborers in the United States.' Medical Anthropology 30(4): 339-362.

Rogaly, B. 2008. 'Intensification of Workplace Regimes in British Horticulture: The Role of Migrant Workers.' Population, Space and Place 14(6): 497-510.

Rye, J.F. 2017. 'Negotiating Neoliberalism: Informalisation and Reformalisation of Industrial Relations in Norway's Agricultural Industry in the 21st Century.' Population, Space and Place 23(7): unpaginated. DOI:10.1002/psp.2042.

Rye, J.F. and J. Andrzejewska. 2010. 'The Structural Disempowerment of Eastern European Migrant Farm Workers in Norwegian Agriculture.' Journal of Rural Studies 26(1): 41-51.

Rye, J.F. and S. Scott. 2018. 'International Labour Migration to/in Rural Europe: A Review of the Evidence.' Sociologia Ruralis 8(4): 928-954.

Sanchez, T.F. 2013. 'Californian Strawberries: Mexican Immigrant Women Sharecroppers, Labor, and Discipline.' Anthropology of Work Review 34(1): 15-26.

Schlosser, E. 1995. 'In the Strawberry Fields.' The Atlantic Monthly 276(5): 80-108.

Scott, S. 2013a. 'Migration and the Employer Perspective: Pitfalls and Potentials for a Future Research Agenda.' Population, Space and Place 9(6): 703-713.

Scott, S. 2013b. 'Migrant-Local Hiring Queues in the UK Food Industry.' Population, Space and Place 19(5): 459-471.

Scott, S. 2017. Labour Exploitation and Work-based Harm. Bristol: Policy Press.

Scott, S. and Rye, J.F. Forthcoming. 'Praised, Prized, yet Penalised: A Critical Examination of Low-wage Hiring Queues in the Global Strawberry Industry.'

Suárez-Orozco, M. and C.E. Suárez-Orozco. 1995. 'The Cultural Patterning of Achievement Motivation: A Comparison of Mexican, Mexican Immigrant, Mexican American, and Non-Latino White American Students.' In California's Immigrant Children: Theory, Research, and Implications for Educational Policy, 
edited by R.G. Rumbaut and W.A. Cornelius, 161-190. San Diego, Center for U.S.Mexican Studies: University of California.

Tannock, S. 2015. 'Bad Attitude? Migrant Workers, Meat Processing Work and the Local Unemployed in a Peripheral Region of the UK.' European Urban and Regional Studies 22: 416-430.

Waldinger, R. and M.I. Lichter 2003. How the Other Half Works: Immigration and the Social Organization of Labor. Berkeley: University of California Press.

Weber, M. [1921] 1968. Economy and Society. An Outline of Interpretive Sociology. Berkeley: University of California Press.

Wells, M. 1996. Strawberry Fields. Politics, Class, and Work in California Agriculture. Ithaca: Cornell University Press.

Yin, R.K. 2009. Case Study Research. Design and Methods. London: Sage. 